\title{
Barnyard Millet as a Substitute of Rice in Preparation of khichdi for Diabetics
}

\author{
Shweta Joshi ${ }^{1}$, Sarita Srivastava ${ }^{2}$ \\ ${ }^{1}$ Research Scholar, Department of Foods \& Nutrition, College of Home Science, G.B. Pant University of Agriculture \& Technology, \\ Pantnagar, Uttarakhand, India, Postal code- 263145 \\ ${ }^{2}$ Professor, Department of Foods \& Nutrition, College of Home Science, G.B. Pant University of Agriculture \& Technology, Pantnagar, \\ Uttarakhand, India, Postal code- 263145
}

\begin{abstract}
Diabetes is among one of the most prevalent chronic disease where diet has a major role to play. Khichdi is a nutritious traditional food most commonly consumed in India. Khichdi contains goodness of both cereal and pulses. Cereal proteins are generally deficient in lysine and pulses (legumes) contain low amount of methionine. However, when both cereals and pulses (legumes) are present in the diet in proper proportions, nutrients from both sources combine to make perfect combination. PRJ-1 variety of barnyard millet was used in preparation of barnyard millet khichdi and Swarna variety of rice was used in preparation of rice khichdi. Bengal gram (legume) was used as common ingredient in preparation of both barnyard millet khichdi and rice khichdi. The results on proximate analysis reveal that except carbohydrate and physiological energy all the values were higher for barnyard millet khichdi. The protein, fat, crude fibre, total minerals, carbohydrate and physiological energy values were $12.28 \mathrm{~g}, 3.84 \mathrm{~g}, 6.44 \mathrm{~g}, 2.61 \mathrm{~g}, 63.7 \mathrm{~g}$ and 338 Kcal/100 $\mathrm{g}$ for barnyard millet khichdi and 8.65, 2.67, 0.61, 1.05, 76.84 and $365 \mathrm{Kcal} / 100 \mathrm{~g}$ for rice khichdi, respectively. Mineral composition viz; calcium, iron, zinc, magnesium, chromium and phosphorus values for barnyard millet khichdi were $27.4,4.44,4.36$, 87.19, 0.039 and $225.3 \mathrm{mg} / 100 \mathrm{~g}$ whereas for rice khichdi the values were 18.73, 3.64, 1.44, 52.87, 0.005 and $171.89 \mathrm{mg} / 100 \mathrm{~g}$, respectively. A non significant difference was observed in sensory characteristics of both barnyard millet khichdi and rice khichdi. Both were under acceptable range of score card and Hedonic scale. The glycemic index of rice khichdi was significantly higher (62.5) than barnyard millet khichdi (34.96) The data thus obtained depict the slow sugar releasing property of barnyard millet making it a best substitute for people suffering from diabetes.
\end{abstract}

Keywords: Diabetes, khichdi, barnyard millet, rice, glycemic index

\section{Introduction}

The word diabetes has originated from Greek, and it means a "siphon". Thomas Willis in 1965 added mellitus to the term diabetes, although it is commonly referred to simply as diabetes. The latin means of Mel is "honey" as the urine and blood of people with diabetes has excess glucose, and glucose is sweet like honey. So the literal meaning of Diabetes mellitus is "siphoning off sweet water". In ancient times, Chinese people observed that ants attract to some people's urine, because it was sweet which gave rise to the term "Sweet Urine Disease"[1]. When food is digested, the glucose enters the bloodstream. The body cells use this glucose for energy and growth. However for glucose to enter the body cells, insulin is needed. Insulin is a hormone that is produced by the pancreas. After consuming food, pancreas itself releases an adequate quantity of insulin to transport the glucose present in blood to the cells and as soon as glucose enters the cells, blood glucose level drops [2]. Diabetes is a condition in which the concentration of glucose in the blood is elevated (hyperglycemia) because either the body does not produce enough insulin, produces no insulin, or the cells do not respond properly to the insulin the pancreas produces. Khichdi is a preparation made from rice and pulses. It is the most common traditional recipe of rice consumed in India. Khichdi is inspired from popular Egyptian dish kushari [3]. Rice due to its high glycemic index is considered unsuitable for people suffering from diabetes. Drastic change in the diet is not desirable in diabetes and dietary modifications in food product make it feasible for the person to consume a diet with habitual and familiar food items. Glycemic index is an important tool used in diet management of people with diabetes and in weight loss programs. Low glycemic index foods, by virtue of the slow digestion and absorption of their carbohydrates, produce a more gradual rise in blood sugar and insulin levels and are increasingly associated with health benefits. Low glycemic index foods have thus been shown to improve the glucose tolerance in both healthy and diabetic subjects [4]. Studies on glycemic index have shown that pulses have low glycemic index value and glycemic index of food is the sum total effect of the ingredients used in the preparation. Physical factors like dietary fibre and its viscosity, high unabsorbable carbohydrate contents and delay gastric empting are responsible for low glycemic index value of pulses [5]-[6].Barnyard millet is a nutritious millet rich in minerals, protein, dietary fibre, resistant starch and antioxidants [7]. Barnyard millet is consumed in scattered pockets of India in boiled form i.e cooked similar to rice hence it may serve as substitute of rice in formulation of khichdi. The study therefore was undertaken with the objective of formulating barnyard millet khichri and comparing its nutritive value, sensory quality and glycemic index with rice khichdi.

\section{Materials and methods}

The study was conducted in the Department of Foods and Nutrition, College of Home Science, G.B. Pant University of Agriculture and Technology, Pantnagar, Uttarakhand. Barnyard millet khichdi was prepared using PRJ-1 variety of barnyard millet and rice khichdi was prepared using Swarna variety of rice with Bengalgram dhal. The ratio of barnyard millet/rice: Bengal gram dhal was 5:1 as suggested by ICMR [8]. According to International Rice Research Institute (IRRI) Swarna variety of rice is commonly consumed in India and has glycemic index value less than 60. Proximate

\section{Volume 5 Issue 6, June 2016 www.ijsr.net}




\section{International Journal of Science and Research (IJSR) \\ ISSN (Online): 2319-7064}

Index Copernicus Value (2013): 6.14 | Impact Factor (2015): 6.391

analysis of PRJ-1 variety of barnyard millet and Swarna variety of rice was done using standard method [9]. Estimation of minerals like calcium, iron zinc, magnesium and chromium was done using atomic absorption spectrophotometer whereas phosphorus was estimated using chemical method [10]. The total dietary fibre content of barnyard millet and rice was estimated using standard method [11] The above nutrient for Bengal gram except total dietary fibre were calculated using food composition tables given by [12]. The sensory evaluation of barnyard millet khichdi and rice khichdi was done using 9 point Hedonic scale and score card method [13].

For evaluation of glycemic index study 10 normal female adult human volunteers of age group between 24-26 years were selected from Gloden Jublee Hostel, G.B.P.U.A\&T, Pantnagar, Uttarakhand. Written consent of the subjects was taken to participate in the study. The subjects were given general instructions to avoid any physical exertion, medication, fast and feast during the experimental period. On the first day glucose tolerance test (GTT) for glucose was conducted on overnight fasted subjects. A $50 \mathrm{~g}$ glucose dissolved in $200 \mathrm{ml}$ water was given to the subjects. The subjects were instructed to finish glucose solution within 15 minutes. The blood glucose level was measured at 0, 30, 60, 90,120 and 150 min using glucometer. On alternate day the barnyard millet Khichdi (raw amount:81g) / rice Khichdi (raw amount: $64.8 \mathrm{~g}$ ) containing $50 \mathrm{~g}$ of available carbohydrate were served to the same subjects with $200 \mathrm{ml}$ of water. The blood glucose was measured initially and at $30,60,90,120$ and 150 min of finishing the product.

GI of barnyard millet khichdi and rice khichdi was calculated according to the formula given below [14]

$\mathrm{GI}=\underline{\text { Incremental area under blood glucose response curve }}$ for food product X 100

Corresponding area after equicarbohydrate portion of glucose

The ingredients used in barnyard millet khichdi have been given in Table 1. No spices were used in preparation of barnyard millet khichdi and rice khichdi to avoid effect of spices in their sensory quality and glycemic index.

\section{Statistical Analysis}

The data was analyzed in Excel sheets and values were expressed as mean, standard deviation. T- test for difference between two means was applied to find out the significant difference between sensory quality and glycemic index values of barnyard millet khichdi and rice khichdi whereas one way ANOVA was applied to find out significant difference between area under blood glucose response curve of glucose, barnyard millet khichdi and rice khichdi.
Table 1: Ingredients used in preparation of khichdi using barnyard millet and rice

\begin{tabular}{|c|c|c|}
\hline \multirow{2}{*}{ Ingredients } & \multicolumn{2}{|c|}{ Amount } \\
\cline { 2 - 3 } & $\begin{array}{c}\text { Barnyard millet } \\
\text { (variety PRJ-1) }\end{array}$ & $\begin{array}{c}\text { Rice } \\
\text { (variety Swarna) }\end{array}$ \\
\hline Barnyard millet /rice & $65 \mathrm{~g}$ & $54 \mathrm{~g}$ \\
Bengal gram dhal & $13 \mathrm{~g}$ & $10.8 \mathrm{~g}$ \\
Salt & $1.10 \mathrm{~g}$ & $1.10 \mathrm{~g}$ \\
Jeera & $0.50 \mathrm{~g}$ & $0.50 \mathrm{~g}$ \\
Oil & $1 / 2 \mathrm{tsp}$ & $1 / 2 \mathrm{tsp}$ \\
Water & $130 \mathrm{ml}$ & $150 \mathrm{ml}$ \\
\hline
\end{tabular}

\section{Results and Discussion}

\section{Nutrient composition of barnyard millet $k$ hichdi and rice khichdi}

The data on nutrient composition of barnyard millet khichdi and rice khichdi presented in Table 2 depicts that except carbohydrate and physiological energy all the values were higher for barnyard millet khichdi. The results on proximate analysis suggest that protein, fat, crude fibre, total minerals, carbohydrate and physiological energy values were $12.28 \mathrm{~g}$, $3.84 \mathrm{~g}, 6.44 \mathrm{~g}, 2.61 \mathrm{~g}, 63.7 \mathrm{~g}$ and $338 \mathrm{Kcal} / 100 \mathrm{~g}$ for barnyard millet khichdi and 8.65, 2.67, 0.61, 1.05, 76.84 and $365 \mathrm{Kcal} / 100 \mathrm{~g}$ for rice khichdi, respectively. Protein, fat, NDF, carbohydrate and energy in barnyard millet khichdi have been reported as $4.01 \mathrm{~g}, 3.67 \mathrm{~g}, 6.13 \mathrm{~g}, 13.08 \mathrm{~g}$, $101 \mathrm{Kcal} / 100 \mathrm{~g}$ [15]. Regarding mineral composition calcium, iron, zinc, magnesium, chromium and phosphorus values for barnyard millet khichdi and rice khichdi were 27.4, 4.44, 4.36, 87.19, 0.039 and 225.3 and 18.73, 3.64, $1.44,52.87,0.005$ and $171.89 \mathrm{mg} / 100 \mathrm{~g}$, respectively (Table 2).the results on total dietary fibre content of barnyard millet and rice revealed that barnyard millet had significantly higher dietary fibre content $(13.3 \mathrm{~g} / 100 \mathrm{~g})$ as compared to rice $(2.96 \mathrm{~g} / 100 \mathrm{~g})$.

Table 2: Nutrient composition of barnyard millet khichdi and rice khichdi (per 100g)

\begin{tabular}{|c|c|c|c|}
\hline S.No & Nutrients (per 100 g) & $\begin{array}{c}\text { Barnyard millet } \\
\text { Khichdi }\end{array}$ & Rice Khichdi \\
\hline 1 & Protein (g) & 12.28 & 8.65 \\
2 & Fat (g) & 3.84 & 2.67 \\
3 & Crude fibre (g) & 6.64 & 0.61 \\
4 & Total minerals (g) & 2.61 & 1.05 \\
5 & Carbohydrate (g) & 63.7 & 76.84 \\
6 & Energy (Kcal) & 338 & 365 \\
7 & Calcium (mg) & 27.4 & 18.73 \\
8 & Iron(mg) & 4.44 & 3.64 \\
9 & Zinc (mg) & 4.36 & 1.44 \\
10 & Magnesium (mg) & 87.19 & 52.87 \\
11 & Chromium (mg) & 0.039 & 0.005 \\
12 & Phosphorus (mg) & 225.3 & 171.89 \\
\hline
\end{tabular}

Sensory quality of barnyard millet khichdi and rice khichdi using score card method

A non significant difference was observed in the sensory characteristics of khichdi prepared from barnyard millet (variety PRJ-1) and rice (variety Swarna). The overall acceptability of barnyard millet khichdi and rice khichdi was 8 and 8.1, respectively. Both were under "Good" category of score card (Table 3). 


\section{International Journal of Science and Research (IJSR) \\ ISSN (Online): 2319-7064}

Index Copernicus Value (2013): 6.14 | Impact Factor (2015): 6.391

Table 3: Sensory quality of khichdi prepared from PRJ-1 variety of barnyard millet and Swarna variety of rice using score card

\begin{tabular}{|c|c|c|c|c|}
\hline S. No. & Characteristics & Barnyard millet khichdi (mean \pm SD) & Rice khichdi (mean \pm SD) & S/NS \\
\hline 1 & Colour & $7.8 \pm 0.84$ & $8.2 \pm 0.42$ & NS \\
\hline 2 & Aroma & $7.9 \pm 0.70$ & $8 \pm 0.47$ & NS \\
\hline 3 & Taste & $8 \pm 0.67$ & $8.1 \pm 0.52$ & NS \\
\hline 4 & Appearance & $8 \pm 0.63$ & $8 \pm 0.73$ & NS \\
\hline 5 & Overall acceptability & $8 \pm 0.67$ & $8.1 \pm 0.52$ & NS \\
\hline
\end{tabular}

\section{$\mathrm{S}=$ significant difference, $\mathrm{NS}=$ non significant difference}

\begin{abstract}
Sensory quality of barnyard millet $k$ hichdi prepared from PRJ-1 variety of barnyard millet and Swarna variety of rice using nine point Hedonic scale

It is clear from Table 4 that Hedonic scale rating also showed non-significant difference in sensory characteristics of khichdi prepared from barnyard millet (variety PRJ-1) and rice (variety Swarna). Both were "liked very much" as per Hedonic scale rating.
\end{abstract}

Table 4: Sensory quality of khichdi prepared from PRJ-1 variety of barnyard millet and Swarna variety of rice using nine point Hedonic scale.

\begin{tabular}{|c|c|c|c|}
\hline $\begin{array}{c}\text { S. } \\
\text { No }\end{array}$ & Food product & $\begin{array}{c}\text { Score } \\
(\text { Mean } \pm \text { SD) }\end{array}$ & Preference \\
\hline 1 & Barnyard millet $\boldsymbol{k h i c h d i}$ & $8.1 \pm 0.67$ & Like very much \\
\hline 2 & Rice $\boldsymbol{k h i c h d i}$ & $8.3 \pm 0.67$ & Like very much \\
\cline { 2 - 3 } & t-value & 0.43 & \\
& S/NS & NS & \\
\hline
\end{tabular}

$\mathrm{S}=$ significant difference, $\mathrm{NS}=$ non significant difference

\section{Estimation of Glycemic Index}

The glycemic index (GI) can be defined as a ranking system that indicates how quickly a food containing carbohydrate raises blood glucose level which is determined by measuring the area under the curve within two hours of test food consumption [16]. Consumption of high-glycemic index (GI) foods result in more rapid as well as higher increase in blood glucose levels as opposed to consumption of lowglycemic (GI) index foods. [17].

\section{Anthropometric characteristics of subjects and their nutrient intake}

All the subjects were between the age group of 24-26 years. The average height and weight of the subjects was $1.58 \mathrm{~m}$ and $57.06 \mathrm{~kg}$, respectively. The body mass index (BMI) of the subjects lies between 20.3 to $23.5 \mathrm{~kg} / \mathrm{m}^{2}$ with an average of $22.51 \mathrm{~kg} / \mathrm{m}^{2}$. The value of BMI indicates that all the subjects were under normal category. All the subjects were free from disease and were not on any kind of medications, fasting and feasting. The blood pressure of all the respondents was found normal. Twenty four hour recall method for one day was used to assess the dietary intake of the subjects which revealed that the average value for carbohydrate, protein, fat and energy intake of subjects was $260.7 \mathrm{~g}, 48.6 \mathrm{~g}, 19.0 \mathrm{~g}$ and $1854.5 \mathrm{kcal} / \mathrm{day}$ respectively as shown in Table 5.
Table 5: Nutrient intake of subjects per day

\begin{tabular}{|c|c|c|}
\hline S.No & Nutrients & Average intake (Mean \pm SD) \\
\hline & Carbohydrate $(\mathrm{g})$ & $260.7 \pm 26.09$ \\
2 & Protein $(\mathrm{g})$ & $48.6 \pm 4.81$ \\
3 & Fat $(\mathrm{g})$ & $19.0 \pm 1.51$ \\
4 & Energy $(\mathrm{Kcal})$ & $1854.5 \pm 66.67$ \\
\hline
\end{tabular}

Glycemic index of barnyard millet khichdi and rice khichdi

Blood glucose levels at 0,30, 60, 90,120 and 150 min after consuming barnyard millet khichdi and rice khichdi containing $50 \mathrm{~g}$ of equicarbohydrate as compared to glucose load of $50 \mathrm{~g}$ are depicted in Table 6 and Figure 1. The highest peak was observed after 30 minutes of intake of glucose, barnyard millet khichdi and rice khichdi. On comparison of all the three curves it was observed that the lowest peak was for barnyard millet khichdi (variety PRJ-1) followed by rice khichdi (variety Swarna) and glucose.

Table 6: Blood glucose levels at different time intervals for barnyard millet khichdi and rice khichdi

\begin{tabular}{|c|c|c|c|}
\hline $\begin{array}{c}\text { Time interval } \\
\text { (minutes) }\end{array}$ & $\begin{array}{c}\text { Glucose } \\
(\mathrm{mg} / 100 \mathrm{ml})\end{array}$ & $\begin{array}{c}\text { Barnyard millet } \\
\text { khichdi } \\
\text { (variety PRJ-1) } \\
\text { (mg/100ml) } \\
\text { (Mean } \pm \text { SD) }\end{array}$ & $\begin{array}{c}\text { Rice khichdi } \\
\text { (variety } \\
\text { Swarna) } \\
(\mathrm{mg} / 100 \mathrm{ml}) \\
(\mathrm{Mean} \pm \mathrm{SD})\end{array}$ \\
\hline $\mathbf{0}$ & $80.5 \pm 3.13$ & $79.7 \pm 3.91$ & $81.1 \pm 2.76$ \\
$\mathbf{3 0}$ & $158.0 \pm 5.88$ & $106.4 \pm 4.90$ & $127.3 \pm 4.98$ \\
$\mathbf{6 0}$ & $125.3 \pm 27.01$ & $96 \pm 4.87$ & $100.3 \pm 1.81$ \\
$\mathbf{9 0}$ & $106.8 \pm 17.29$ & $89.9 \pm 4.22$ & $92.7 \pm 1.63$ \\
$\mathbf{1 2 0}$ & $100.8 \pm 12.86$ & $84.5 \pm 3.97$ & $88.8 \pm 2.69$ \\
$\mathbf{1 5 0}$ & $89.2 \pm 5.96$ & $81.5 \pm 3.24$ & $85.2 \pm 2.29$ \\
\hline
\end{tabular}

The area under blood glucose response curve was lowest for barnyard millet khichdi $(1793.5 \mathrm{mg} \mathrm{min} / 100 \mathrm{ml})$ followed by rice khichdi (3137.2 $\mathrm{mg} \mathrm{min} / 100 \mathrm{ml})$ and glucose $(5009.2 \mathrm{mg}$ $\mathrm{min} / 100 \mathrm{ml}$ ) (Table 7). This indicates that on consumption of barnyard millet khichdi there is slow release of glucose which helps to maintain normal blood glucose level, a desirable characteristic for diabetes. The area under blood response curve for barnyard millet khichdi have been reported as $1840.03 \pm 382.09 \mathrm{mg} . \mathrm{min} / 100 \mathrm{ml} \mathrm{[15].} \mathrm{Legumes}$ are categorised by National Diabetes Mellitus (DM) guidelines among the lowest glycemic index (GI) foods. Bengal gram dhal is among most commonly consumed legume in India. It has been reported that the low-glycemic index legume diet reduces glycosylated heamoglobin values by 0.5 per cent as compared to high wheat fibre diet which reduces glycosylated heamoglobin value up to 0.3 per cent. The study states that incorporation of legumes improves glycemic control and also reduces risk of cardiovascular disease risk in diabetic subjects [18]-[19]. 


\section{International Journal of Science and Research (IJSR) \\ ISSN (Online): 2319-7064 \\ Index Copernicus Value (2013): 6.14 | Impact Factor (2015): 6.391}

Table 7: Area under blood glucose response curve for barnyard millet khichdi and rice khichdi

\begin{tabular}{|c|c|c|}
\hline S. No & Food product & $\begin{array}{c}\text { Area (mg min/100ml) } \\
(\text { mean } \pm \text { SD) }\end{array}$ \\
\hline $\mathbf{1}$ & Glucose & $5009.2 \pm 326.2$ \\
$\mathbf{2}$ & Barnyard millet $\boldsymbol{k h i c h d i}$ & $1793.5 \pm 314.1$ \\
$\mathbf{3}$ & Rice $\boldsymbol{k h i c h d i}$ & $3137.2 \pm 235.7$ \\
& S.Em & 98 \\
& CD at 5\% & 117.6 \\
\hline
\end{tabular}

S.Em - standard error of mean, CD - critical difference

Therefore the glycemic index (34.96) of barnyard millet khichdi (variety PRJ-1) was comes under low glycemic index foods category according to the classification [20]. The risk of developing long term complications can be reduced dramatically by consuming right kind of food resulting in appropriate glycemic control in persons with diabetes.The glycemic index of rice khichdi (variety Swarna) was significantly higher than barnyard millet khichdi. Refined carbohydrates like white rice are devoid of fibre, raises blood glucose level much faster than their intact and unprocessed forms. When it is consumed, the blood sugar level immediately shoots up and the body produces excess insulin to lower the blood sugar level. Barnyard millet due to presence of good amount of dietary fibre results in slow release of glucose in the blood rather than a sharp increase caused by consumption of rice making it a best substitute of rice for the people suffering from diabetes. The data thus obtained reveals that the barnyard millet khichdi had very slow release of blood sugar, a quality suited and desirable for diabetic patients.

Table 8: Glycemic index of barnyard millet khichdi and rice khichdi

\begin{tabular}{|c|c|c|}
\hline S.No. & Food product & $\begin{array}{c}\text { Glycemic index } \\
(\text { mean } \pm \text { SD) }\end{array}$ \\
\hline $\mathbf{1}$ & Barnyard millet $\boldsymbol{k h i c h d i}$ & $34.96 \pm 1.22$ \\
$\mathbf{2}$ & Rice khichdi & $62.5 \pm 1.38$ \\
& t-value & 4.67 \\
& S/NS & $\mathrm{S}$ \\
\hline
\end{tabular}

$\mathrm{S}=$ significant difference, $\mathrm{NS}=$ non significant difference

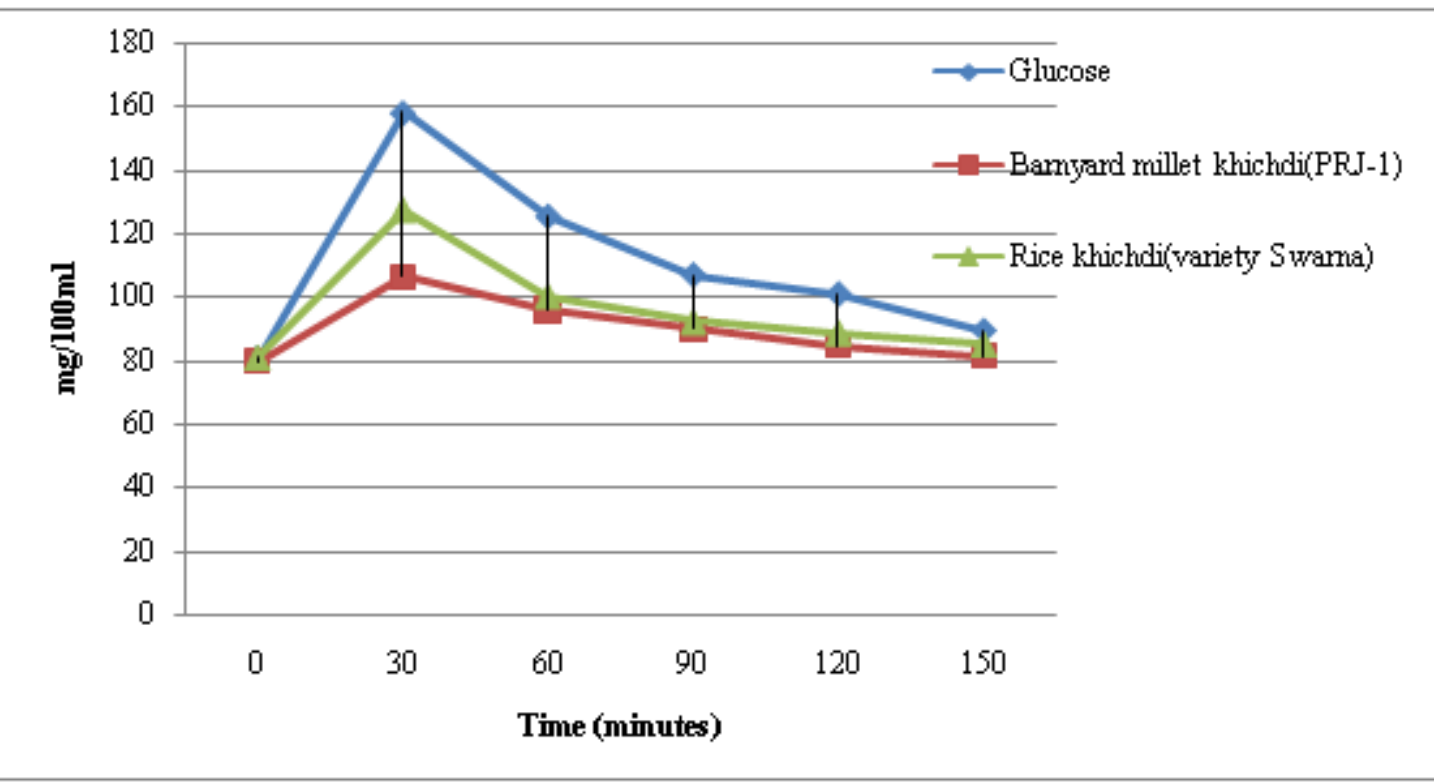

Figure 1: Blood glucose response curve for barnyard millet khichdi (variety PRJ-1) and rice khichdi (variety Swarna) in comparison to glucose load of $50 \mathrm{~g}$

\section{Conclusion}

The study undertaken on barnyard millet as a substitute of rice in the form of khichdi was found suitanle for diabetes. The nutritional analysis results suggest that except carbohydrate and physiological energy other proximate values viz; protein, fat, crude fibre and ash content of barnyard millet khichdi were higher as compared to rice khichdi. Similar results were observed for mineral composition suggesting that barnyard millet khichdi has higher values for calcium, phosphorus, iron, zinc, magnesium and chromium as compared to rice khichdi. No significant difference was observed in sensory quality of barnyard millet khichdi and rice khichdi. Highly significant difference was observed between glycemic index values of barnyard millet khichdi and rice khichdi suggesting slow sugar releasing property of barnyard millet khichdi.

\section{Acknowledgement}

The authors acknowledge Department of Foods and Nutrition, College of Home Science, G.B. Pant University of Agriculture and Technology, Pantnagar, Uttarakhand for providing all the facilities and guidance during the course of research work and Department of Science and Technology (New Delhi) for providing financial assistance through INSPIRE fellowship programme.

\section{References}

[1] Medical dictionary..http://medicaldictionary.thefreedictionary.com/diabetes+mellitus,201 5

[2] Nix, S.. Basic nutrition and diet therapy. $13^{\text {th }}$ edition. Delhi Elsevier publishers.188.201p, 2009

\section{Volume 5 Issue 6, June 2016 www.ijsr.net}




\section{International Journal of Science and Research (IJSR) \\ ISSN (Online): 2319-7064}

Index Copernicus Value (2013): 6.14 | Impact Factor (2015): 6.391

[3] Monier . A Sanskrit-English Dictionary. Delhi: Motilal Banarsidass. 339p, 1995

[4] Jenkins, D.J.A., T.M.S. Wolever, G. Buckley, K.Y. Lam, S. Giudici and J. Kalmusky,. Low-glycemic-index starchy foods in the diabetic diet. Am. Journal of Clinical Nutrition. 48: 248-254, 1988

[5] Jenkins, D.J.A., T.M.S. Wolever and R.M. Taylor,. Rate of digestion of foods and postpradial glycemia in normal and diabetic subjects. British Medical Journal. 281: 14-17, 1980

[6] Holt, S., R.C. Heading and D.C. Carta,. Effect of gel fiber on gastric emptying and absorption of glucose and paracetamol. Lancet., 1: 636-39, 1979.

[7] Ugare, R., Chimmad, B., Naik, R., Bharati, P. and Itagi S. Glycemic index and significance of barnyard millet (Echinochloa frumentacae) in type II diabetics. Journal of Food Science and Technology. 51(2):392-395, 2014

[8] Indian Council of Medical Research (ICMR).. Nutrient requirements and recommended dietary allowances for Indians. A report of the expert group of the Indian council of medical research.National institute of nutrition. Andhra Pradesh, 2010

[9] AOAC. Official methods of analysis of the association of official analytical chemists. $16^{\text {th }}$ ed. Washington D. C., U. S. A, 1995.

[10]Fiske, C.H. and Subbarow, Y. The colorimetric determination of phosphorus. Journal of Biological Chemistry. 66:375-400, 1925

[11] Asp, N.G., Johansson, C.G.. Techniques for measuring dietary fibre. In: James WPT, Theander O, editors. The analysis of dietary fibre in food. New York, Marcel Dekker. pp. 173-189, 1981

[12] Gopalan, C., Ramshashtri, B.V., Balasubramaniam, S.C. Nutritive value of Indian foods, National Institute of Nutrition, ICMR, Hyderabad, 2007.

[13] Amerine, N.A., Pangborn, R.M. and Roessler, E.B. Principles of sensory evaluation of food. New York. Academic Press. 1965

[14] Wolever, T.M.S.. The glycemic index. World Review of Nutrition and Dietetics. 62 : 120-185, 1990.

[15] Arora and Srivastava. Suitability of millet based food products for diabetics. Journal of Food Science and Technology. 39 (4) : 423-428, 2002.

[16] Kirpitch A. R. and Maryniuk, M.D. The 3 R's of Glycemic Index: Recommendations, Research, and the Real World. Clinical Diabetes. 29 (4): 155-159, 2011.

[17]Ludwig, D.S. The glycemic index: physiological mechanisms relating to obesity, diabetes, and cardiovascular disease. Journal of American Medical Association. 287(18):2414-2423, 2002.

[18] Jenkins, D.J.A., Kendall, C.W.C., Augustin, L.S.A., Mitchell, S., Pudaruth, S.S., Mejia, S.B., Chiavaroli, L., Mirrahimi, Christopher, A., Bashyam, B., Vidgen, E., Souza, R.J.D., Sievenpiper, J.L., Coveney, J., Leiter, L.A., and Josse, R.G. Effect of legumes as part of a low glycemic index diet on glycemic control and cardiovascular risk factors in type 2 diabetes mellitus. Annals of International Medicine. 172 (21):1653-1660, 2012.

[19] Barclay, A.W., Petocz, P., Price, J.M., Flood, V.M., Prvan, T., Mitchell, P. and Brand- Miller, J.C. Glycemic index, glycemic load, and chronic disease risk-a meta- analysis of observational studies. American Journal of Clinical Nutrition. 87 (3): 627-637, 2008.

[20] Brand-Miller. J, Wolever. T.M.S. Colagiuri, S. and Foster-Powell, K. The glucose revolution. New York. Marlowe and Company, 1999. 